ppi $201502 Z U 4645$

Esta publicación cientifica en formato digital es continuidad de la revista impresa ISSN-Versión Impresa 0798-1406 / ISSN-Versión on line 2542-3185Depósito legal pp

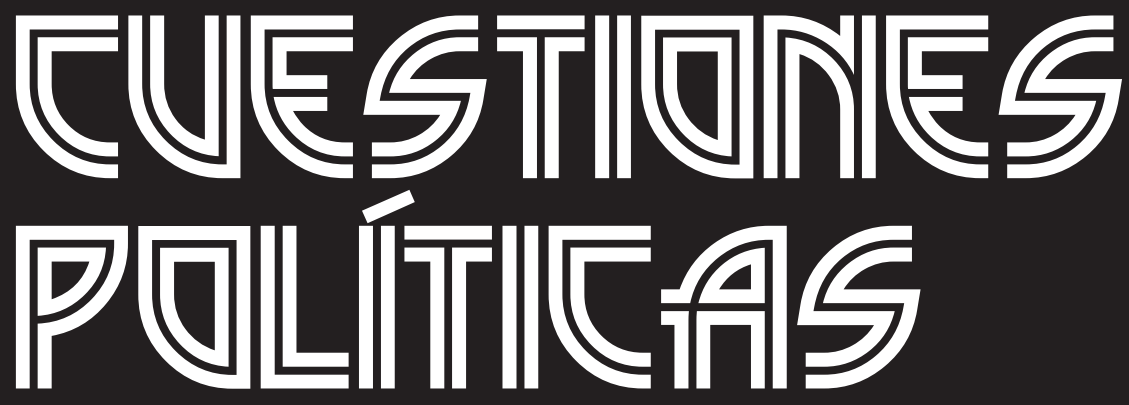

Instituto de Estudios Políticos y Derecho Público "Dr. Humberto J. La Roche' de la Facultad de Ciencias Jurídicas y Políticas de la Universidad del Zulia Maracaibo, Venezuela
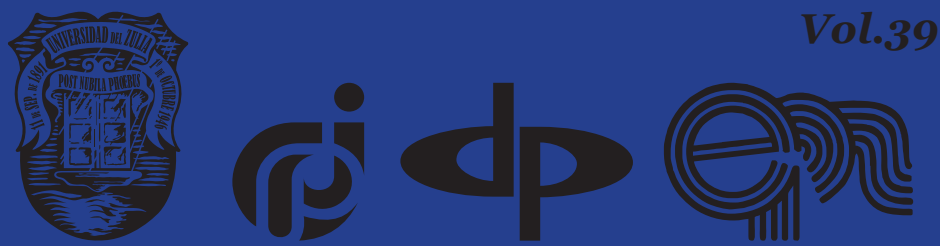


\title{
International Legal Problems of Qualification of Armed Conflicts
}

\author{
DOI: https://doi.org/10.46398/cuestpol.3968.47
}

\author{
Mykhaylo Buromenskiy * \\ Vitalii Gutnyk **
}

\begin{abstract}
The article addresses the qualification problems of armed conflicts. The study was conducted through the analysis of international legal doctrine, international treaties, decisions of international organizations. Attention is paid to the jurisprudence of the International Criminal Tribunal for the former Yugoslavia and the International Criminal Court. It is noted that International Humanitarian Law has been in place since the beginning of the armed conflict. Therefore, the application of International Humanitarian Law does not require any recognition of the existence of armed conflict (international or non-international); this conflict exists because of armed clashes. It is emphasized that the need to classify the conflict arises in view of domestic and international legal factors (to bring to international criminal justice those who have committed war crimes; state responsibility for internationally wrongful acts, etc.). Attention was paid to the non-existence of a single body, which was empowered to determine the existence of an armed conflict. Different international agencies may have different qualifications for the same armed conflict. It is concluded that it is necessary to establish a Committee of Experts under the UN SecretaryGeneral, to avoid different qualifications from the same armed conflict.
\end{abstract}

Keywords: armed conflict; war; crime's war; hybrid warfare; International Criminal Court.

* Doctor of legal sciences, professor of International Law Department, Taras Shevchenko National University of Kyiv, Ukraine. ORCID ID: https://orcid.org/oooo-0002-9287-5116. Email: mykhayloburomenskiy@gmail.com

** Doctor of legal sciences, professor of International Law Department, Ivan Franko National University of Lviv, Ukraine. ORCID ID: https://orcid.org/oooo-ooo3-1401-4393. Email: vitalik_gutnik@ukr.net 


\section{International Legal Problems of Qualification of Armed Conflicts \\ Problemas jurídicos internacionales de calificación de los conflictos armados}

\section{Resumen}

El artículo aborda los problemas de calificación de los conflictos armados. El estudio se realizó mediante el análisis de la doctrina jurídica internacional, tratados internacionales, decisiones de organismos internacionales. Se presta atención a la jurisprudencia del Tribunal Penal Internacional para la ex Yugoslavia y la Corte Penal Internacional. Se observa que el Derecho Internacional Humanitario se ha venido aplicando desde el inicio del conflicto armado. Por tanto, la aplicación del Derecho Internacional Humanitario no requiere ningún reconocimiento de la existencia del conflicto armado (internacional o no internacional); este conflicto existe por el hecho de enfrentamientos armados. Se enfatiza que la necesidad de calificar el conflicto surge en vista de los factores de orden legal interno e internacional (para llevar ante la justicia penal internacional a quienes han cometido crímenes de guerra; responsabilidad del Estado por hechos internacionalmente ilícitos, etc.). Se prestó atención a que no existe un organismo único, que esté facultado para determinar la existencia de un conflicto armado. Diferentes organismos internacionales pueden tener diferentes calificaciones para el mismo conflicto armado. Se concluye que es necesario establecer una Comisión de Expertos dependiente del Secretario General de la ONU, a fin de evitar diferentes calificaciones de un mismo conflicto armado.

Palabras clave: conflicto armado; guerra; crímenes de guerra; guerra híbrida; Corte Penal Internacional.

\section{Introduction}

Wars have accompanied human civilization during its history, and today it is difficult to imagine what would be the development of society if states had invested their scientific and human potential, as well as financial resources into the overall well-being of humanity, rather than the development of weapons and warfare. Nowadays, it is not possible to calculate victims of the wars and claim the exact toll of human lives. And it is impossible to say surely what our society could be without such conflicts. Unfortunately, for many countries, the priority remains the armed forces, waging war, and not the well-being of its population.

Wars force us to rethink not only human values, but also the values based on which the state and the world community as a whole must function. That is why each new stage of development of public international law is connected with the existing crises of world scale and the desire of states 
to revise the 'rules of the game' in the international arena to prevent such crises in the future.

However, armed conflicts are still existing; this is reality of nowadays. Therefore, the issue of qualification of armed conflicts is continuing to be actual.

Qualification of armed conflicts is needed both to determine which norms of the International Humanitarian Law (IHL) are applicable to armed conflict and, if it violated, to bring the perpetrators to justice before national and international courts. In addition, depending on the type of armed conflict, the international legal responsibility of the state may arise.

This article is devoted to analyzing of the existing problems of international legal qualification of armed conflicts, investigating and detecting who has the right to qualify armed conflicts and what are the consequences of such qualifications. In the article is solved the following tasks:

- to define the types of armed conflict.

- to characterize the current problems in the practice of qualifying armed conflicts by state.

- to find out the specific features of the qualifying of armed conflicts by international organizations and international criminal courts.

- to formulate suggestions concerning body that should define the existence or absence of armed conflicts.

\section{Theoretical Framework}

The qualification of armed conflicts has been the subject of research by scholars. Sylvain Vite in his article "Typology of armed conflicts in international humanitarian law: legal concepts and actual situations" studied international and non-international armed conflicts, as well as paid special attention to "controversial classification of certain armed conflicts", in particular: "control of a territory without military presence on the ground", "foreign intervention in non-international armed conflicts" (Vite, 2009: 83). In the article "Armed conflict under international humanitarian law", O. C. Nwachukwu made similar work researching the specific features of international, non-international and mixed armed conflicts (Nwachukwu, 2014). A comparison of the term's "war" and "armed conflict" was made by V. Bernard (Bernard, 2014).

James G. Stewart and Dietrich Schindler studied internationalized armed conflict. In the scientific article "Towards a Single Definition of Armed Conflict in International Humanitarian Law: a Critique of 
Internationalized Armed Conflict” J. G. Stewart paid attention to the test for internationalization of armed conflict, the effect of internationalization, and political influence on characterization of internationalized armed conflict (Stewart, 2003). Dietrich Schindler in his work "International humanitarian law and internationalized internal armed conflicts" researched different relationships in internationalized internal armed conflicts and forcible installation of a new government through the intervention of a foreign State (Schindler, 1982).

Hybrid warfare was subject of study firstly by F. G. Hoffman (Hoffman, 2009). After this, hybrid warfare as an armed conflict, waged by specific methods was subject of researching by M. A. Piotrowski (Piotrowski, 2015), N. Antonyuk and M. Malskyy (Antonyuk and Malskyy, 2016), S. Iqbal (Iqbal, 2018), A. Celso (Celso, 2019), etc.

\section{Methodology}

Thestudywas conducted through thecritical analysis ofinternationallegal doctrine, international treaties, decisions of international organizations. Particular attention is paid to the case-law of the International Criminal Tribunal for the former Yugoslavia and the International Criminal Court.

The subjects of the research were customary and treaty norms of IHL as well as practice of international criminal courts. The subject of the study were armed conflicts (Arakelian et al., 2020)

Dialectical, comparative, historical and formal dogmatic methods are used in this article.

\section{Types of armed conflicts}

\subsection{International and non-international armed conflicts}

Traditionally, the norms of IHL distinguish two types of armed conflicts: international and internal (non-international).

International armed conflict is considered as a conflict which occurs between two or more States, and non-international is a conflict, between governmental forces and non-governmental armed groups, or between only these groups (Melzer, 2016; Djukić and Pons, 2018; Tileubergenov et al., 2016). As Nils Melze stresses:

For centuries, sovereign States have regulated their relations in both peace and war through treaties and custom, a tradition based on mutual recognition of national sovereignty and international legal personality. Conversely, governments have long been reluctant to subject their efforts to maintain law and order and public security within their territorial borders to the purview of international law (Melzer, 2016: 53). 
Essentially, states do not want to provide any guarantees for separatists, and they want to have a free hand in "internal affairs" (Cameron, 2008; Thürer, 2011). The legal regulation of international armed conflicts is carried out primarily by the Geneva Conventions of 1949 and the Additional Protocol I to the Geneva Conventions of 1977.

Article 2 of the Geneva Conventions of 1949 provides the commonly accepted definition of an international armed conflicts. In accordance with common art. 2 to the Geneva Conventions of 1949 this Convention is applying to all cases of declared war or of any other armed conflict that arising between two or more of countries, even if the state of war is not recognized by one of that countries; the Convention is applying also to all cases of occupation (partial or total) of the territory of a state, even if the said occupation does not meet with armed resistance.

Certainly, an international armed conflict is foremost an inter-state conflict. But at the same time, the Additional Protocol I extend the definition of international armed conflicts. According to art. 1 (4) of the Protocol, international armed conflicts also include "armed conflicts in which peoples are fighting against colonial domination and alien occupation and against racist régimes in the exercise of their right of self-determination".

Hence, IHL provides for two types of international armed conflicts: 1) inter-state conflict (classic inter-state warfare and partial or total occupation) and 2) armed conflict in accordance with the principle of selfdetermination (wars of national liberation).

The legal regulation of non-international armed conflicts is carried out by the common art. 3 to Geneva Conventions of 1949 and the Protocol Additional to the Geneva Conventions of 1949 and Relating to the Protection of Victims of Non-International Armed Conflicts (Protocol II).

According to art. 1 (1) of the Protocol II, internal armed conflicts are armed conflict between armed forces of state and dissident armed forces or "other organized armed groups which, under responsible command, exercise such control over a part of its territory as to enable them to carry out sustained and concerted military operations and to implement this Protocol". Hence, non-international armed conflict means armed conflict that take place either between 1) one or more armed groups and government's forces or 2) only between armed groups (Vite, 2009).

At the same time, according to art. 1 (2) of the Protocol II, noninternational armed conflicts do not cover situations of internal disturbances and tensions, including "riots, isolated and sporadic acts of violence and other acts of a similar nature, as not being armed conflicts".

The general distinction between internal (non-international) armed conflicts and situations of internal disturbances and tensions is made by two criteria: 


\section{International Legal Problems of Qualification of Armed Conflicts}

1) hostilities must be a minimum level of intensity (this criterion includes the duration, number and intensity of individual confrontations; the type of weapons used; the number and caliber of munitions; the number of persons and type of armed forces partaking in the fighting; the number of victims; involvement of UN Security Council etc.) (International Criminal Tribunal for the Former Yugoslavia, 2008; Wilmshurst, 2012; Gill and Fleck, 2015; Murray, 2016).

2) non-governmental armed forces involved in the conflict are "parties to the conflict", meaning that they are organized armed forces (Luban et al., 2018; Ziadeh, 2019; ICRC, 2008).

In the context of the study of international / non-international armed conflicts, it should be noted that the term "armed conflict" has almost completely supplanted the term "war". Sometimes it chances to find the opinion that "war" is only a political term, in contrast to "armed conflict", which has a legal meaning in contemporary IHL (Bernard, 2014). With this opinion can only be partially agreed. Indeed, after the Second World War, in particular in the 1949 Geneva Conventions, the term "war" is used much less frequently than "armed conflict". Moreover, the 1949 Geneva Conventions introduced the concept of armed conflict into IHL in the first time. S. Vite emphasizes that:

Those who drafted those instruments wanted to show that the applicability of IHL was henceforth to be unrelated to the will of governments. It was no longer based solely on the subjectivity inherent in the recognition of the state of war but was to depend on verifiable facts in accordance with objective criteria (Vite, 2009: 72).

At the same time, IHL continues to use concepts of "laws and customs of war", "war crimes". Moreover, the title of the Third Geneva Convention (1949) "The Third Geneva Convention relative to the treatment of prisoners of war" and the Fourth Geneva Convention (1949) "Geneva Convention relative to the protection of civilian persons in time of war". The term "war" can also be found in the text of the 1949 Geneva Conventions. That is, in IHL, the aspect has changed from "war" to "armed conflict", but the term "war" continues to be used.

\subsection{Other possible types of armed conflict in the doctrine of IHL and the practice of international criminal tribunals}

As noted above, the norms of IHL distinguish two types of armed conflicts: international and non-international (internal). At the same time other types of armed conflicts can be found in the doctrine and the practice of international criminal tribunals. Why do new types of armed conflict begin to emerge in the doctrine and practice? The reason for this 
seems to be that the definition of international / non-international conflicts contains the ideal constructions, because any armed conflict cannot be exclusively international or non-international. As a consequence, since every international armed conflict has more or less armed clashes that can be defined as a non-international armed conflict, and conversely, in a non-international armed conflicts can be involved a third country that will internationalize such conflict, and therefore the concepts of other types of armed conflict are emerged: internationalized, mixed and hybrid armed conflict (Dzhafarova et al., 2020).

\section{a. Internationalized armed conflict}

The treaty norms of IHL contain no specific provisions on internationalized armed conflicts. As usually, the term "internationalized armed conflict" scientists describe as non-international armed conflict that are rendered international (Stewart, 2003; Cassese, 2009; Melzer, 2016). It is worth paying attention to the opinion of J.G. Stewart, who emphasizes that the factual circumstances can achieve internationalization are as usually combined and includes armed conflict between two internal groups (both are supported by different States); "direct hostilities between two States that militarily intervene in an internal armed conflict" to support opposing sides; armed conflicts "involving a foreign intervention in support of an insurgent group" fighting against governmental armed forces (Stewart, 2003: 315).

Since the treaty rules of IHL do not define the internationalized armed conflict, the question arises which rules of IHL should be applied to such conflict: those applicable to international or non-international armed conflicts? By the way, the problem of application of IHL to internationalized armed conflict is not so new. As D. Schindler underlined, back at the time of the Vietnam armed conflict in the 1960s, two different opinions were offered concerning the applicability of IHL in internationalized armed conflicts (Schindler, 1982). According to one, a non-international armed conflict becomes an international by the mere fact of armed intervention by foreign state. IHL should be applied to all the parties of the armed conflict, even between the government of the State in which the non-international armed conflict has broken out and the insurgents. According to the other opinion, an internationalized armed conflict should be divided into its international and non-international components (Schindler, 1982).

It seems that the rightest position on the application of IHL to internalized armed conflicts is now adopting by the ICRC. According to the position of ICRC in an internalized armed conflict could be defined three situations: 1) it remains a non-international (when one or more (third) States or an international organization intervene in support of a state involved in a war 


\section{2 \\ Mykhaylo Buromenskiy y Vitalii Gutnyk \\ International Legal Problems of Qualification of Armed Conflicts}

against an organized armed group); 2) it becomes an international (when one or more (third) States or an international organization intervene in support of an organized armed group involved in a war against government forces); 3) it becomes "mixed" (depending on the nature of parties to the armed conflict).

\section{b. "Mixed" armed conflict}

The treaty norms of IHL contain no specific provisions also on "mixed" armed conflicts.

'Mixed' armed conflicts mean conflicts that combine, on the one hand, international, and on the other hand, non-international armed conflicts (Bouvier, 1986; Nwachukwu, 2014). In such conflicts it is possible to define clearly in which cases there is an international one and in which there is a non-international armed conflict.

Concept of "mixed" armed conflict was used in the practice of the International Criminal Tribunal for the former Yugoslavia (ICTY) (Kolb and Hyde, 2008; Doria et al., 2009). In the Tadic case, the Appeals Chamber of the ICTY stressed that the members of the UN Security Council knew in 1993 (during drafting of the Statute), that in the former Yugoslavia the armed conflicts could have been characterized as both international and non-international, or alternatively, as a non-international armed conflict alongside an international one, or as a non-international conflict that had become internationalized because of support of the third state, or as an international conflict that had afterward been replaced by one or more non-international conflicts, or some combination (international/ internal) these conflicts (International Criminal Court, 1995). Moreover, the different nature of the conflicts in the former Yugoslavia is in evidence by the agreements reached by parties to conflicts in order to abide by certain norms of IHL. The Appeals Chamber of the ICTY (Tadic case) emphasized that the fact reflecting the conflict being international is that on 27 November 1991 representatives of the Yugoslavia Peoples' Army, the Federal Republic of Yugoslavia, Croatia, and the Republic of Serbia reached into an agreement on the implementation of the Geneva Conventions of 1949 and the Additional Protocol I of 1977 (International Criminal Court, 1995). In contrast to the abovementioned agreement, an agreement reached on 22 May 1992 between the various factions of the conflict within the Bosnia and Herzegovina reflected the non-international aspects of the conflicts (International Criminal Court, 1995).

At the same time, the weakness of the conception of "mixed" armed conflict is fairness of the division of participants in armed conflicts, when in hostilities take part the governmental armed forces on the one hand and the anti-governmental armed forces and their supporting third-country 
governmental forces are involved in armed clashes on the other hand. Would it be fair to distinguish such persons, in particular by providing different levels of protection by IHL treaties? In reality, the Geneva Conventions of 1949 and the First Additional Protocol of 1977 will apply to governmental armed forces, and only Common article 3 to the Geneva Conventions and the Additional Protocol II of 1977 to anti-governmental forces.

\section{c. Hybrid warfare}

The concept of "hybrid warfare" is not common used in international legal doctrine. International law norms do not contain the concept of 'hybrid warfare' either. However, this concept is used actively to characterize armed conflict in Syria (Celso, 2019), Lebanon (Piotrowski, 2015), Libya (Iqbal, 2018) etc.

The concept of "hybrid warfare" is still more military and political than legal. One of the authors of this concept is Frank G. Hoffman, who speaking about hybrid warfare, mainly draws attention to the methods of such warfare. In particular, in his view, hybrid warfare brings together regular and irregular armed forces, state and non-state actors; involvement of high-tech capabilities such as antisatellite weapons with terrorism etc. (Hoffman, 2009).

S. Iqbal gave very similar notion of hybrid warfare and including to hybrid warfare political war, conventional and unconventional warfare, information and cyber warfare, supporting local unrest, mass propaganda (including fake news), diplomacy, intervention in foreign elections (Iqbal, 2018). Hybrid warfare is seen as an armed conflict, waged by specific methods by a number of other scientists too (Josan and Voicu, 2015; Lanoszka, 2016).

However, the question arises whether it is advisable to use the term 'hybrid' instead of the term 'international' / 'non-international' in modern armed conflicts? It seems that the classic division of armed conflicts (international / non-international) contains some ideal constructions. Because it is difficult to imagine any armed conflict that would be exclusively international or non-international, especially that did not contain "political wars", information wars and propaganda, partial support from the local people in the form of collaborators, etc. If we rethink the Second World War, based on the above definition of hybrid warfare, this war, which contained mass propaganda (Welch, 2017), active use of collaborators (Armstrong, 1968) etc., could also be considered "hybrid". Certainly, such a course of thinking about the classification of the Second World War as "hybrid" is false. The example of World War II is just one example that confirms that the term "hybrid" war can be applied to any armed conflict. Further, if this term can be applied to any armed conflict and apriori all armed conflicts 


\section{Mykhaylo Buromenskiy y Vitalii Gutnyk

are hybrid, then the expediency of using such a term is lost because it does not allow to distinguish one armed conflict from another.

Besides, qualifying an armed conflict, it is necessary to find out who is organizing this conflict. The concept of hybrid warfare minimizes the possibility of identifying the parties of armed conflict (regardless of whether it is an international or internal (non-international) conflict). The application of the concept of hybrid warfare creates the problem of compliance with IHL obligations, including related to prohibited methods and means of warfare, as well as the protection of victims of war.

\subsection{The practice of qualifying armed conflicts: current problems}

As outlined above, the Geneva Conventions of 1949 apply to all cases of armed conflicts (international or non-international). ICRC paid attention, that "when the armed forces of two States are involved, suffice it for one shot to be fired or one person captured (in compliance with government instructions) for IHL to apply" (ICRC, 2011; Fundamentals of IHL, 2011). Hence, IHL has been applied since the fact of beginning of the armed conflict. As a result, to begin applying IHL does not require any decision of state or international organization (or any other subject), including a decision concerning a type of armed conflict. But at the same time, in case of violation of IHL, responsibility arises both within the framework of national and international justice, the qualification of armed conflict may be made by the state or international courts. An international organization can also qualify an armed conflict.

\subsection{Qualifying armed conflicts by state}

Since States are parties of the Geneva Conventions of 1949 and the Additional Protocols of 1977, so the primary responsibility for qualifying an armed conflict lies on the States. But, even if a state does not recognize that there is an armed conflict in its territory (but, for example, recognize the existence of a counter-terrorist operation), it does not mean that there is no armed conflict; in this case the IHL must also be applied.

As stressed above, nowadays there are no direct obligations of state to establish the existence of an armed conflict in order to apply IHL. Drafters of The Geneva Conventions of 1949 wanted to show that the applicability of IHL was henceforth to be unrelated to the wishes of states (Vite, 2009). S. Vite pointed, "it was no longer based solely on the subjectivity inherent in the recognition of the state of war, but was to depend on verifiable facts in accordance with objective criteria" (Vite, 2009: 72). 
At the same time, the Geneva Conventions of 1949 oblige States to take measures to criminalize certain violations of IHL, which may be regarded as "grave breaches", and to prosecute persons who committed them. However, after the entry into force of the Geneva Conventions and the first Additional Protocol, customary international law has evolved and demanded that all "serious violations" of IHL (not merely "grave breaches") be investigated and prosecuted (Global Rights Compliance, 2016).

States have primary responsibility for bringing to justice those who have committed serious violations of the IHL (Radosavljevic, 2008; Konforta and Vajda, 2014; Hoon, 2017). Undoubtedly, in order to establish which norms of the IHL were violated it is necessary for state to determine first which (international or non-international) armed conflict took place.

\subsection{Qualifying of armed conflicts by international organization}

International organizations may qualify armed conflict. But taking into account the limited scope of this scientific article we will focus more on the qualification of armed conflict by the UN Security Council.

In accordance with the art. 24 (1) of the UN Chapter, the UN Security Council has the "primary responsibility for the maintenance of international peace and security". In view of this, the Security Council uses the right to qualify the existence of armed conflict (Resolution 771, 1992; Resolution 918, 1994; Resolution 2259, 2015; Resolution 2042, 2012; Resolution 2139, 2014). It should be noted that the UN Security Council is very cautious in classifying armed conflicts. The Security Council as usually, does not use the words "international armed conflict" or "non-international armed conflict" in its resolutions. However, it is possible to find out from the text of the resolutions which armed conflict is in question, in particular when analyzing which parties of the armed conflict are involved, which treaty norms should be applied by the parties of the conflict etc. Also the UN Security Council uses the term "occupation" rarely and very cautiously (Resolution 884, 1993).

Defacto, the UN Security Council also qualified an armed conflict through its resolutions, establishing international criminal tribunals, including the ICTY and the International Criminal Tribunal for Rwanda (ICTR). The ICTR's ratione materiae jurisdiction over war crimes is defined in Art. 4 of the ICTR Statute and covers "Violations of Article 3 Common to the Geneva Conventions and of Additional Protocol II". Therefore, conclusion can be made based on the ICTR Statute that, the UN Security Council qualified in 1994 the armed conflict in Rwanda as a non-international armed conflict. Instead, according to Art. 2 and Art. 3 of the Statute of the ICTY, war crimes are divided into two groups "grave breaches of the Geneva Conventions of 
Mykhaylo Buromenskiy y Vitalii Gutnyk
746 International Legal Problems of Qualification of Armed Conflicts

1949" and "violations of the laws or customs of war". As a result, the armed conflict in the former Yugoslavia was not limited to any type of armed conflicts.

UN Security Council, determining that the situation in state continues to constitute a threat to international peace and security may refer the situation to the International Criminal Court (ICC). UN Security Council used this power referring the situation in Darfur (Sudan) (Resolution 1593, 2005) and Libya (Resolution 1970, 2011) to the ICC. In fact, this referral confirmed of the existence of an armed conflict.

\subsection{Qualifying of armed conflicts by international criminal courts}

International criminal courts, that have power to prosecute for committing of war crimes, also can qualify armed conflicts. Qualification of armed conflict by international criminal courts will be considered in more details in the example of the ICTY and the ICC.

As emphasized by L.R. Blank and G.P. Noone, in the conflict in the former Yugoslavia, conflict characterization was put the test multiple times over the course of the conflict (Blank and Noone, 2018). Slovenia and Croatia declared independence from Yugoslavia in May 1991. After 10 days of fighting, Yugoslav forces withdrew from Slovenia. Armed conflict continued in Croatia and spread to Bosnia in May 1992 when Bosnia and Herzegovina also declared independence. Serbs in Bosnia formed a separate Bosnian Serb entity ("Republika Srpska") and fighting between and among all three ethnic groups exploded. Over the next three years, the world learned of concentration camps, ethnic cleansing, mass killings, and other atrocities throughout Bosnia and the contested portions of Croatia (Blank and Noone, 2018). The conflict in Bosnia-Herzegovina ended in November 1995 with the reaching of the General Framework Agreement on Peace (the so-called "Dayton Agreement"); in Croatia it ended with the signing of the Erdut Agreement (was signed in November 1995 as well) (Young, 2001).

When the UN Security Council established the ICTY in 1993, it did not specify what type of armed conflict took place in the former Yugoslavia. According to UN Security Council Resolution 827 only decided that the ICTY is established "for the sole purpose of prosecuting persons responsible for serious violations of IHL committed in the territory of the former Yugoslavia..." (Resolution 827, 1993). To prosecute, the ICTY was empowered to determine the type of armed conflict.

The definition of armed conflict was given by the ICTY in the D. Tadic case: 
An armed conflict exists whenever there is a resort to armed force between States or protracted armed violence between governmental authorities and organized armed groups or between such groups within a State. IHL applies from the initiation of such armed conflicts and extends beyond the cessation of hostilities until a general conclusion of peace is reached; or, in the case of internal conflicts, a peaceful settlement is achieved (International Criminal Court, 1995: 70).

In Blaskić case, Trial Chamber of the ICTY, found, that an armed conflict which begins in the territory of one State and which is thus at first view non-international may be deemed as international where the armed forces of another State intervene in the conflict or at least where some participants in the non-international armed conflict act on behalf of this other State (International Criminal Tribunal for the Former Yugoslavia, 2000) and based on Croatia's direct intervention in Bosnia and Herzegovina, the Trial Chamber of the ICTY defined that this conflict as international (International Criminal Tribunal for the Former Yugoslavia, 2000). Similar decision of the Trial Chamber was in Kordić and Čerkez case, where Chamber finds that "the conflict between the Bosnian Croats and the Bosnian Muslims in Bosnia and Herzegovina was internationalized by the intervention of Croatia in that conflict through its troops" (International Criminal Tribunal for the Former Yugoslavia, 2001).

In the Statute of the International Criminal Court (ICC) ratione materiae jurisdiction over war crimes is defined in Art. 8 and includes war crimes committed both during international and non-international armed conflicts.

The ICC has paid attention, that the concept of armed conflict, is not defined in the Statute or in the Elements of Crimes of the ICC but is developed at other international courts and the ICC has derived assistance from the jurisprudence of the ICTY (Tadic case) (International Criminal Court, 2018; 2012; 2014). The ICC has accepted the definition of armed conflict given by the ICTY in the abovementioned D. Tadic case (International Criminal Court, 2018; 2012; 2014).

The ICC repeatedly qualified armed conflicts. In D. Ongwen case, to define the contextual element of article 8 (War crimes) of the Statute of the ICC, Pre-Trial Chamber concluded existence of a non-international armed conflict: From 1 July 2002 to 31 December 2005 a protracted internal armed conflict between the government armed forces of Uganda (together with associated local armed units in northern Uganda) and the Lord's Resistance Army (LRA). These hostilities exceeded, in intensity, internal disturbances and tensions (International Criminal Court, 2016).

In the case of Lubanga Dyilo, Trial Chamber I of the ICC concerning the mental element in conduct of T. Lubanga, concluded that he was aware of the factual circumstances that established the existence of noninternational armed conflict and he was the fully aware connection "between 


\section{International Legal Problems of Qualification of Armed Conflicts}

the crimes of conscripting and enlisting children under the age of 15 to use them to participate in the armed conflict or the factual circumstances that established the existence of the armed conflict" (International Criminal Court, 2012: 1349-1350).

In the same time, the ICC concluded existence in the Democratic Republic of the Congo (DRC) number of simultaneous armed conflicts (both international and non-international armed conflict). Chamber considered that as a result of the presence of Uganda as an occupying Power, the armed conflict which occurred in Ituri could be defined as an international armed conflict from July 2002 to 2 June 2003 (the date of the effective withdrawal of the Ugandan armed forces) (International Criminal Court, 2007). Protracted violence carried out by multiple non-state armed groups remained an internal armed conflict "notwithstanding concurrent international armed conflict" (International Criminal Court, 2012: 563).

It should be emphasized that the ICC qualifies the existence of an armed conflict linked to the alleged war crimes in context of separate accused. Therefore, if the accused persons committed different war crimes in the same state, different qualifications of the armed conflict could be possible, including different time frames for the existence of the same armed conflict.

For example, in the Al Mahdi case (situation in Mali), Trial Chamber VIII of the ICC found that in Mali a non-international armed conflict existed between Malian Government forces and groups including Ansar Dine and AQIM: "During the time frame of the facts alleged in that case, namely between approximately 30 June 2012 and 11 July 2012" (International Criminal Court, 2016: 38).

But in $\mathrm{Al}$ Hassan case (the same situation in Mali), Pre-Trial Chamber I of the ICC, to decide question concerning the issuance of a warrant for the arrest of Al Hassan Ag Abdoul Aziz Ag Mohamed Ag Mahmoud considered it necessary to deal with question of this armed conflict in Mali in respect of his case (International Criminal Court, 2018).

About jurisdiction ratione materiae (war crimes), in view of the totality of the material submitted, the Chamber found than non-international armed conflict existed in Mali between January 2012 and January 2013 between the government's armed forces of Mali and several non-state armed groups including Ansar Dine and AQIM (International Criminal Court, 2018).

That is, in the first case (Al Mahdi case), the ICC found that noninternational armed conflict in Mali existed for less than one month (between 30 June 2012 and 11 July 2012), in another (Al Hassan case) - one year (between January 2012 and January 2013). Hence, the ICC defines the existence of an armed conflict to find the contextual element of article 8 (War crimes) of the Statute of the ICC and takes into consideration war crimes attributed to particular person. 


\section{Discussion}

As noted above, IHL has been applied since the fact of beginning of the armed conflict. Therefore, in general, to apply IHL do not need any recognition of the armed conflict; it exists due to the fact of armed clashes and not since the moment of the statement of its existence. However, the need for qualification of armed conflict arises in view of both the factors of domestic and international legal order.

In case of an armed conflict on the territory of a state, the government of such state needs to define an appropriate legal regime in the hostilities zone. On the other hand, the relevant legal regime should be defined within the framework of the international legal order, to bring to justice those who have committed war crimes, as well responsibility of state for internationally wrongful acts.

As it can be seen from the above study of the practice of qualifying armed conflicts, there is no single body that is entitled to determine the existence of an armed conflict.

States themselves can determine the existence of an armed conflict in their territory. But even if states determine that there is no armed conflict at all and there is, for example, an anti-terrorist operation's regime, that does not mean that there is no armed conflict (Antonyuk and Malskyy, 2016); IHL will be applied in this situation and violations of these norms will mean responsibility for this.

The UN Security Council may also determine the existence of an armed conflict. However, in the last few decades, the Security Council has shown its Inefficiency; its decisions are often politicized (Peters, 2016; Kolb, 2017). In addition, the qualification of an armed conflict by the UN Security Council is not binding on other international institutions.

International criminal courts are also empowered to determine the existence of an armed conflict. But international criminal courts decide on the qualification of an armed conflict in relation to a specific case in the context of war crimes charges. Therefore, as it is seen in the above study on the qualification by the ICC of the armed conflict in the situation in Mali, the same armed conflict was recognized in one case (Al Mahdi case) as having existed for two weeks (between 30 June 2012 and 11 July 2012) and in the other case (Al Hassan case) for one year (between January 2012 fand January 2013).

Therefore, each subject may qualify the armed conflict, and such qualification is not compulsory for other subjects.

It seems that the legal identification for the existence of an armed conflict should be exercised by a single body that would be independent and impartial. In fact, this will make it possible to achieve legal certainty 
Mykhaylo Buromenskiy y Vitalii Gutnyk
$750 \quad$ International Legal Problems of Qualification of Armed Conflicts

about the existence (or absence) of an armed conflict with all possible legal consequences.

At first sight, such an authority could be the International Committee of the Red Cross (ICRC), which operates based on principles "humanity, impartiality, neutrality, independence, voluntary service, unity and universality" (art. 4 (1) (a) of the Statutes of the ICRC).

On the other hand, the ICRC's main goal protection of and assistance to military and civilian victims of armed conflict and of their direct results (Zwitter et al., 2015). Therefore, the ICRC avoids political statements that can complicate relations with the parties of armed conflict and protection of victims of war. Hence, given the fact that the ICRC is trying as an impartial organization to maintain good relations with the parties of the conflict (to facilitate the protection of victims of war), empowering the ICRC to determine the type of armed conflict will be ineffective.

Then who may determine the existence of an armed conflict? It seems that a new permanent body of the United Nations - the Commission of Experts for determination of armed conflicts should be established for this purpose, that will be authoritative and non-political. The Commission should be composed of 11-15 experts who would have the necessary experience and have an impeccable reputation. Such a Commission should be established as a subsidiary body under the UN Secretary-General. The Commission, as a subsidiary body, should carry out the identification of armed conflicts in order to take such identification as a basis for further qualification by the competent body.

It should be noted that the UN has the practice of establishing of a commission of experts ad hoc. For analyzing of information on the armed conflict in the former Yugoslavia in accordance with the Security Council Resolution 780 (1992) of 6 October 1992 by the Secretary-General was established the Commission of Experts to examine and analyze information to providing the UN Secretary-General "with its conclusions on the evidence of grave breaches of the Geneva Conventions and other violations of IHL committed in the former Yugoslavia" (Resolution 780, 1992). Commission of Expert was empowered to obtain information "through its own investigation or efforts" (Resolution 780, 1992).

Among other things, this Commission stated in its Final Report that the armed conflict in the former Yugoslavia had a mixed (international / non-international) character but emphasized that "determining when these conflicts are internal and when they are international is a difficult task because the legally relevant facts have not been generally agreed upont" (United Nations, Security Council, 1992: 43). The Commission was one of the initiators of the establishment of the ICTY (Aksar, 2004). 
Returning to the permanent Committee of Experts that is proposed to establish to qualify all armed conflict, it seems that the Commission should be formed of highqualified and impartial persons and the results of the work of these will be beyond doubt. The mechanism for appointing such persons should be non-political, transparent, and effective to prevent the appointment of non-qualified persons to the Commission.

\section{Conclusions}

According to the treaty norms of IHL, there are only two types of armed conflicts: 1) international and 2) non-international.

The division into international and non-international conflicts contains the ideal constructions because any armed conflict cannot be exclusively international or non-international. Therefore, since every international armed conflict has armed clashes that can be defined as a non-international armed conflict, and conversely, in a non-international armed conflict a third country can be involved that will internationalize such conflict, therefore the concepts of other types of armed conflict are emerged: internationalized, mixed and hybrid armed conflict. Today it is difficult to imagine any armed conflict that would not contain "political wars", information wars and propaganda, partial support from the local people in the form of collaborators, etc.

Nevertheless, the practice is that, in the end, every armed conflict is classified as international or non-international, or at the same time the regime of both international and non-international armed conflict is applied.

IHL has been applied since the fact of beginning of the armed conflict. Therefore, applying IHL does not need any recognition of existence of the armed conflict; this conflict exists due to the fact of armed clashes. But at the same time, the need to qualify an armed conflict arises in view of both the factors of domestic (to define a legal regime in the hostilities zone) and international legal order (to bring to international criminal justice those who have committed war crimes; responsibility of state for internationally wrongful acts etc.). The practice of qualification of armed conflicts is shown that there is no single body who is entitled to determine the existence of an armed conflict. Therefore, different international bodies, or even the same body (including the ICC) may have different qualifications of the onearmed conflict.

It seems that a new permanent body of the United Nations - the Commission of Experts should be established to define of an armed conflict. The Commission should be authoritative and non-political and composed of 11-15 experts who would have the necessary experience and have an impeccable reputation. 
Mykhaylo Buromenskiy y Vitalii Gutnyk
752 International Legal Problems of Qualification of Armed Conflicts

\section{Bibliographic References}

AKSAR, Yusuf. 2004. Implementing International Humanitarian Law: From the Ad Hoc Tribunals to a Permanent International Criminal Court. Routledge. London and New York.

ANTONYUK, Natalya; MALSKYY, Markiyan. 2016. "Russia's Hybrid Warfare against Ukraine in the context Of European Security" In: Visnyk of the Lviv University. Series International Relations. No. 38, pp 23-42.

ARAKELIAN, Minas; BEKHRUZ, Khashmatulla; YAROVA, Liliana.2020. "Prohibited means and methods of armed conflicts" In: Amazonia Investiga. Vol. 9, No. 26, pp. 349-355.

ARMSTRONG, John A. 1968. "A. Collaborationism in World War II: The Integral Nationalist Variant in Eastern Europe" Journal of Modern History. Vol. 40, No. 3, pp. 396-410.

BERNARD, Vincent. 2014. "Delineating the boundaries of violence" In: International Review of the Red Cross. Vol. 96, No. 893, pp 5-11.

BLANK, Laurie; NOONE, Gregory P. 2018. International Law and Armed Conflict: Fundamental Principles and Contemporary Challenges in the Law of War. Wolters Kluwer Law \& Business. New York, USA.

BOUVIER, Antoine A. 1986. "The application of international humanitarian law particularly in mixed conflicts" In: International Review of the Red Cross. Vol. 26, No. 251, pp. 129-130.

CAMERON, Iain. 2008. Individual Responsibility under National and International Law for the Conduct of Armed Conflict. Ola Engdahl, Pål Wrange eds. Law at war: the law as it was and the law as it should be. BRILL. Leiden and Boston, USA.

CASSESE, Antonio. 2009. The Oxford Companion to International Criminal Justice. Oxford University Press. Oxford, England.

CELSO, Anthony. 2019. "Superpower Hybrid Warfare in Syria” In: The Marine Corps gazett. Vol. 9, No. 2, pp 92-116.

DJUKIĆ, Draža; PONS, Niccolò. 2018. A Companion to International Humanitarian Law. BRILL. Leiden and Boston, USA.

DORIA, Jose; GASSER, Hans-Peter; BASSIOUNI, Mahmoud Cherif. 2009. The Legal Regime of the International Criminal Court: Essays in Honour of Professor Igor Blishchenko. BRILL. Leiden and Boston, USA. 
DZHAFAROVA, Maryna; IVANOVA, Hanna; ZAHORODNIUK, Svitlana; ZAIETS, Uliana. 2020. "Ensuring Public Order during the Court Hearings in the Context of Reforming the Judicial System of Ukraine" In: Amazonia Investiga. Vol. 9, No. 32, pp 10-17.

UNITED NATIONS, SECURITY COUNCIL. 1994. Final Report of the Commission of Experts established pursuant to Security Council Resolution 780. 1992. Annex to the Letter dated 24 May 1994 from the Secretary-General to the President of the Security Council (27 May 1994, UN Doc.: S/1994/674). Available online. In: https://undocs. org/S/1994/674. Consultation date: 27/01/2020.

GILL, Terry D; FLECK, Dieter. 2015. The Handbook of the International Law of Military Operations. Oxford University Press. Oxford, England.

GLOBAL RIGHTS COMPLIANCE. 2016. The Domestic Implementation of International Humanitarian Law in Ukraine. Available online. In: https://www.globalrightscompliance.com/uploads/e6foccdo36b6f83ff e2b94f3e19983eo.pdf. Consultation date: 27/01/2020.

HOFFMAN, Frank. G. 2009. "Hybrid Warfare and Challenges" In: Small Wars Journal. No. 52, pp. 34-39.

HOON, Marieke. 2017. "Navigating the Legal Horizon: Lawyering the MH17 Disaster" In: Utrecht Journal of International and European Law. Vol. 33, No. 84, pp 90-119.

ICRC. 2011. Fundamentals of IHL. Available online. In: https://casebook.icrc. org/law/fundamentals-ihl\#b_iii_1. Consultation date: 27/01/2020.

ICRC. 2008. Opinion Paper. How is the Term "Armed Conflict" Defined in International Humanitarian Law? International Committee of the Red Cross (ICRC). Available online. In: https://www.icrc.org/en/doc/ assets/files/other/opinion-paper-armed-conflict.pdf. Consultation date: 27/01/2020.

ICRC. 2011. Internationalized internal armed conflict. Available online. In: https://casebook.icrc.org/glossary/internationalized-internal-armedconflict. Consultation date: 27/01/2020.

IQBAL, Saghir. 2018. Hybrid Warfare and its Impact on Pakistan's Security: Hybrid Warfare and its Impact on Pakistan's Security. CreateSpace Independent Publishing Platform. California, USA.

JOSAN, Andrei; VOICU, Cristina. 2015. "Hybrid Wars in the Age of Asymmetric Conflicts" In: Review of the Air Force Academy. Vol. 28, No. 1, pp 49-52. 
Mykhaylo Buromenskiy y Vitalii Gutnyk
754 International Legal Problems of Qualification of Armed Conflicts

KOLB, Andreas S. 2017. The UN Security Council Members' Responsibility to Protect: A Legal Analysis. Springer. Berlin.

KOLB, Robert; Hyde, Richard. 2008. An Introduction to the International Law of Armed Conflicts. Bloomsbury Publishing. Oxford and Portland, England.

KONFORTA, Marijana; VAJDA, Maja Munivrana. 2014. The Principle of Complementarity in the Jurisprudence of the ICC. In: Zagreb Law Review. No. 3/1. pp 9-28.

LANOSZKA, Alexander. 2016." Russian hybrid warfare and extended deterrence in eastern Europe" In: International Affairs. No. 92 (1), pp. 175-195.

LUBAN, David; O'SULLIVAN, Julie R; STEWART, David. P. 2018. International and Transnational Criminal Law. Wolters Kluwer Law \& Business. Alphen aan den Rijn, Netherlands.

MELZER, Nils. 2016. International humanitarian law: a comprehensive introduction. ICRC.

MURRAY, Daragh. 2016. Practitioners' Guide to Human Rights Law in Armed Conflict. University Press. Oxford, England.

NWACHUKWU, Okubor Cecil. 2014. "Armed conflict under international humanitarian law" In: Nnamdi Azikiwe University Journal of International Law and Jurisprudence. Vol, 5, pp 62-74.

PETERS, Anne. 2016. Beyond Human Rights: The Legal Status of the Individual in International Law. Cambridge University Press. Cambridge, England.

PIOTROWSKI, Marcin Andrzej. 2015. "Hezbollah: The Model of a Hybrid Threat” In: PISM Bulletin. No. 24, pp 1-2.

INTERNATIONAL CRIMINAL COURT. 2016. Prosecutor v. Ahmad Al Faqi Al Mahdi, Situation in Mali. ICC-01/12-01/15, Judgment and Sentence. Available online. In: https://www.icc-cpi.int/CourtRecords/ CR2016_07244.PDF. Consultation date: 27/01/2020.

INTERNATIONAL CRIMINAL COURT. 2018. Prosecutor v. Al Hassan Ag Abdoul Aziz Ag Mohamed Ag Mahmoud, Situation in Mali. ICC-01/1201/18. Decision on the Prosecutor's Application for the Issuance of a Warrant of Arrest for Al Hassan Ag Abdoul Aziz Ag Mohamed Ag Mahmoud. Available online. In: https://www.icc-cpi.int/CourtRecords/ CR2018_05010.PDF. Consultation date: 27/01/2020. 
INTERNATIONAL CRIMINAL TRIBUNAL FOR THE FORMER YUGOSLAVIA. 1995. Prosecutor v. D. Tadic: Case No. IT-94-1 (Appeals Chamber): Decision on the Defence Motion for Interlocutory Appeal On Jurisdiction. Available online. In: https://www.icty.org/x/cases/tadic/ acdec/en/51002.htm. Consultation date: 27/01/2020.

INTERNATIONAL CRIMINAL COURT. 2016. Prosecutor v. Dominic Ongwen, Situation in Uganda. ICC-02/04-01/15. Decision on the confirmation of charges against Dominic Ongwen. Available online. In: https://www. icc-cpi.int/CourtRecords/CR2016_02331.PDF. Consultation date: 27/01/2020.

INTERNATIONAL CRIMINAL COURT. 2014. Prosecutor v. Germain Katanga. ICC-01/04-01/07, Situation in the Democratic Republic of the Congo. Judgment pursuant to article 74 of the Statute. Available online. In: https://www.icc-cpi.int/CourtRecords/CR2015_04025.PDF.

INTERNATIONALCRIMINALTRIBUNALFORTHEFORMERYUGOSLAVIA. 2001. Prosecutor v. Kordić \& Čerkez: Case No. IT-95-14/2-T: Judgement. Available online. In: https://www.icty.org/x/cases/kordic_cerkez/tjug/ en/kor-tjo10226e.pdf. Consultation date: 27/01/2020.

INTERNATIONAL CRIMINAL TRIBUNAL FOR THE FORMER YUGOSLAVIA. 2008. Prosecutor v. Ramush Haradinaj, Idriz Balaj, Lahi Brahimaj. Case No. IT-04-84-T. Judgement. Available online. In: https://www.icty.org/x/cases/haradinaj/tjug/en/o80403.pdf. Consultation date: 27/01/2020.

INTERNATIONAL CRIMINAL TRIBUNAL FOR THE FORMER YUGOSLAVIA. 2000. Prosecutor v. T. Blaskić: Case No.: IT-95-14-T: Judgement. Available online. In: https://www.icty.org/x/cases/blaskic/ tjug/en/bla-tjoo0303e.pdf. Consultation date: 27/01/2020.

INTERNATIONAL CRIMINAL COURT. 2007. Prosecutor v. Thomas Lubanga Dyilo, Situation in the Democratic Republic of the Congo. ICC-01/0401/o6. Decision on the confirmation of charges. Available online. In: https://www.icc-cpi.int/CourtRecords/CR2007_02360.PDF. Consultation date: 27/01/2020.

INTERNATIONAL CRIMINAL COURT. 2012. Prosecutor v. Thomas Lubanga Dyilo, Situation in the Democratic Republic of the Congo. ICC-01/0401/o6. Judgment pursuant to Article 74 of the Statute. Available online. In: https://www.icc-cpi.int/CourtRecords/CR2012_03942.PDF. Consultation date: 27/01/2020. 
Mykhaylo Buromenskiy y Vitalii Gutnyk
756 International Legal Problems of Qualification of Armed Conflicts

RADOSAVLJEVIC, Dragana. 2008. "Overview of the ICC Complementarity Regime" In: USAK Yearbook of International Politics and Law. No. 1, pp. 125-148.

RESOLUTION 1593. 2005. United Nations Security Council. Available online. In: https://undocs.org/en/S/RES/1593(2005). Consultation date: 27/01/2020.

RESOLUTION 1970. 2011. United Nations Security Council, 26 February 2011. Available online. In: https://undocs.org/en/S/RES/1970\%20(2011). Consultation date: 27/01/2020.

RESOLUTION 2042. 2012. United Nations Security Council, 14 April 2012. Available online. In: https://undocs.org/S/RES/2042(2012). Consultation date: 27/01/2020.

RESOLUTION 2139. 2014. United Nations Security Council, 22 February 2014. Available online. In: https://undocs.org/en/S/RES/2139(2014). Consultation date: 27/01/2020.

RESOLUTION 2259. 2015. United Nations Security Council, 23 December 2015. Available online. In: https://undocs.org/S/RES/2259(2015). Consultation date: 27/01/2020.

RESOLUTION 771. 1992. United Nations Security Council, 13 August 1992. Available online. In: https://undocs.org/S/RES/771(1992). Consultation date: $27 / 01 / 2020$.

RESOLUTION 780. 1992. United Nations Security Council, 6 October 1992. Available online. In: https://undocs.org/S/RES/780(1992). Consultation date: 27/01/2020.

RESOLUTION 827. 1993. United Nations Security Council, 25 May 1993. Available online. In: https://www.un.org/en/ga/search/view_doc. asp?symbol=S/RES/827(1993). Consultation date: $27 / 01 / 2020$.

RESOLUTION 884. 1993. United Nations Security Council, 12 November 1993. Available online. In: https://undocs.org/S/RES/884(1993). Consultation date: 27/01/2020.

RESOLUTION 918. 1994. United Nations Security Council, 17 May 1994. Available online. In: https://undocs.org/en/S/RES/918(1994). Consultation date: 27/01/2020.

SCHINDLER, Dietrich. 1982. "International humanitarian law and internationalized internal armed conflicts" In: International Review of the Red Cross. Vol. 22, No. 230, pp. 255-264. 
STATUTE OF THE INTERNATIONAL CRIMINAL TRIBUNAL FOR RWANDA. 1994. Adopted 8 November 1994 by Security Council Resolution 955 (1994). Available online. In: https://legal.un.org/avl/ pdf/ha/ictr_EF.pdf. Consultation date: 27/01/2020.

STATUTE OF THE INTERNATIONAL CRIMINAL TRIBUNAL FOR THE FORMERYUGOSLAVIA. 1993. Adopted 25 May 1993 by Security Council Resolution 827 (1993). Available online. In: https://www.icty.org/x/file/ Legal\%20Library/Statute/statute_septo9_en.pdf. Consultation date: 27/01/2020.

STATUTES OF THE INTERNATIONAL COMMITTEE OF THE RED CROSS. 2018. Adopted on 21 December 2017 and came into force on 1 January 2018. Available online. In: Retrieved from: https://www.icrc.org/en/ download/file/63668/icrc-statutes-01-2018.pdf. Consultation date: 27/01/2020.

STEWART, James. G. 2003. "Towards a Single Definition of Armed Conflict in International Humanitarian Law: a Critique of Internationalized Armed Conflict” In: International Review of the Red Cross. Vol. 85, No. 850, pp 313-349.

THÜRER, Daniel. 2011. International Humanitarian Law: Theory, Practice, Context. BRILL. Leiden and Boston, USA.

TILEUBERGENOV, Erazak Manapovich. 2016. "Political and Legal Defining the Regulations of War in the Hague Convention of 1907” In: Journal of Advanced Research in Law and Economics. Vol. 7, No. 3, pp. 660-671.

VITE, Sylvain. 2009. “Typology of armed conflicts in international humanitarian law: legal concepts and actual situations3" In: International Review of the Red Cross. Vol. 91, No. 873, pp 69-94.

WELCH, David. 2017. World War II Propaganda: Analyzing the Art of Persuasion during Wartime. ABC-CLIO. Santa Barbara, USA.

WILMSHURST, Elizabeth. 2012. International Law and the Classification of Conflicts. OUP. Oxford, England.

YOUNG, Kirsten. 2001. "UNHCR and ICRC in the former Yugoslavia: BosniaHerzegovina” In: International Review of the Red Cross. Vol. 83, No. 843, pp. 781-805.

ZIADEH, Radwan. 2019. Accountability in Syria: Achieving Transitional Justice in a Postconflict Society. Rowman \& Littlefield. Lanham.

ZWITTER, Andrej; LAMONT, Christopher K; HEINTZE, Hans-Joachim; HERMAN, Joost. 2015. Humanitarian Action: Global, Regional and Domestic Legal Responses. University Press. Cambridge, England. 

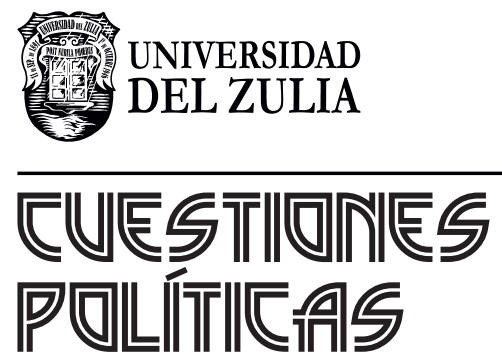

Vol.39 No 68

Esta revista fue editada en formato digital y publicada en enero de 2021, por el Fondo Editorial Serbiluz, Universidad del Zulia. Maracaibo-Venezuela 